\title{
RESPONSABILIDADE DE PROTEGER: MINORIAS E GENOCÍDIO
}

\author{
RESPONSIBILITY TO PROTECT: MINORITIES AND GENOCIDE
}

\author{
Marco Aurélio Moura dos Santos* \\ Frédéric Walthère Joachim Pili**
}

\begin{abstract}
Resumo:
Este artigo busca esclarecer o conceito de responsabilidade de proteger com base na defesa de minorias e luta contra o genocídio na região de Darfur no Sudão. Haverá uma breve análise do andamento dos procedimentos no Tribunal Penal Internacional (TPI).
\end{abstract}

Palavras-chave: Tribunal Penal Internacional. Genocídio. Minorias. Darfur. Responsabilidade de proteger. Organização das Nações Unidas.

\begin{abstract}
:
This paper aims to explicit the concept of responsibility to protect in the defence of minorities and struggle against genocide in the region of Darfur in Sudan. There will be a brief analysis of the proceedings before the International Criminal Court (ICC).
\end{abstract}

Keywords: International Criminal Court. Genocide. Minorities. Darfur. Responsibility to Protect. United Nations.

\section{Introdução}

Após os horrores cometidos sem reação internacional no Ruanda e na Bósnia e diante da resposta inadequada da Organização do Tratado do Atlântico Norte (OTAN) no Kosovo, houve a preocupação da Organização das Nações Unidas (ONU) de elaborar respostas efetivas a crimes internacionais. (INTERNATIONAL COMMISSION ON INTERVENTION AND STATE SOVEREIGNTY, 2001, p. 1-2).

A responsabilidade de proteger (responsibility to protect na sua versão inglesa original ou $R 2 P$ ) se vê como o meio para a comunidade internacional de proteger populações ameaçadas de genocídio, relativizando inclusive o princípio da não intervenção e o da soberania. (THAKUR, 2016, p. 417). Que seja claro aqui: não se trata de um meio de afastar a soberania do estado sobre sua própria população, mas apenas a faculdade de a comunidade internacional assumir este papel, relativizando a soberania, durante certo

Doutorando em Direito Internacional pela FDUSP. Mestre em Direito da Sociedade da Informação - FMU/ SP. Docente da Escola de Direito - FMU/SP. Pesquisador do GEPIM/USP.

** Mestrando em Direito Internacional pela FDUSP. Bacharel em Direito pela PUC/SP. Pesquisador do GEPIM/USP. Advogado militante. Graduado em História pela Universidade de Liège (Bélgica). Mestre em Direito da Integração Europeia e em Relações Internacionais pela mesma Universidade de Liège. 
lapso de tempo em caso de violações graves dos direitos humanos. Essa obrigação se traduz pela responsabilidade de prevenir, a responsabilidade de agir e a responsabilidade de reconstruir frente aos crimes tipificados no Estatuto de Roma de 1998. (WILSON, 2014, p. 159-160). É uma modulação da soberania e da ordem jurídica interna para preservar os bens maiores tutelados pelo Direito Internacional pós-moderno. (GIANNATTASIO, 2018, p. 9).

Mas a responsabilidade de proteger visa a atender as esperanças do sul global que deseja por um fim na intervenção militar das antigas metrópoles coloniais sob o pretexto falacioso de salvar vidas. Por isso, a R2P só pode ser permitida pela ONU. (THAKUR, 2016, p. 418). Outra condição: o risco de se cometer massacres de larga escala, com ou sem intenção genocidária. (INTERNATIONAL COMMISSION ON INTERVENTION AND STATE SOVEREIGNTY, 2001, p. 32).

Ela permite aos estados falidos pedirem ajuda e auxílio à comunidade internacional ou à comunidade internacional assumir o papel de proteção, caso o estado não esteja mais em posição de exercer tal prerrogativa. (WOODWARD, 2012, p. 82-97). Foi o que ocorreu na Líbia em setembro de 2011 quando da proibição de sobrevoo do território líbio pelas forças de Kadhafi para evitar um massacre. A Resolução n. 2.009 do Conselho de Segurança neste mesmo espírito exige a presença das minorias dentro do processo político de transição. (UNITED NATIONS, 2011).

Determinados autores veem a R2P como uma modernização e uma ampliação do conceito de guerra justa que visaria a superar o dilema do mundo moderno entre o paradigma wesfaliano e a proteção dos direitos humanos. Dentro desse contexto, a soberania não é mais puro controle sobre a população, mas a responsabilidade do estado pela proteção dessa mesma população perante ameaças internas e externas ao estado. (IANCU, 2014, p. 344). De fato, seus “princípios de precaução”, a saber: intenção justa, último recurso, meios proporcionais e perspectivas razoáveis de sucesso lembram as características da guerra justa. (INTERNATIONAL COMMISSION ON INTERVENTION AND STATE SOVEREIGNTY, 2001, p. XII).

Outros autores negam sua juridicidade, por conta da falta de positivação do conceito. Para esses autores, o conceito tem reflexo sobre as relações internacionais, como fator meramente político, sem que haja impacto sobre o Direito Internacional. (ROY, 2014, p. 211-212).

De qualquer forma, ao ser usado apenas na Líbia e, em grau menor, na Síria, será que não representa uma herança da política de intervenção armada do Ocidente no Oriente? (SAID, 1979, p. 11). 
Tal situação seria um reflexo da velha concepção racista de que os Árabes seriam incapazes de se governar por eleição? ${ }^{1}$

\section{Os precedentes perante a ONU}

Em primeiro lugar, vale a pena lembrar que a R2P não determina se é o caso de intervir, mas qual é a melhor forma de intervenção. (WOODWARD, 2012, p. 88).

A regulamentação da responsabilidade de proteger civis em conflitos armados se dá por meio da Resolução n. 1.674 do Conselho de Segurança. (WILSON, 2014, p. 165).

A primeira autorização do uso da força contra um regime político com base na responsabilidade de proteger foi dada por meio da Resolução n. 1.973, diante da repressão de Kadhafi contra seu povo. O caso da Líbia mostrou a ambiguidade do uso da responsabilidade de proteger, pois a força militar, qualquer que seja sua legitimidade, foi usada como mais um meio de derrubar um regime considerado como hostil pelo Ocidente. (WILSON, 2014, p. 164-165).

3. O papel respectivo do Tribunal Penal Internacional (TPI) e do Conselho de Segurança (CSNU) da ONU

A responsabilidade de proteger se declina em três modalidades: a responsabilidade de prevenir que é da competência do estado, a responsabilidade de agir por parte da comunidade internacional e a responsabilidade de reconstruir. (MILLS, 2015, p. 75). No caso do Darfur, a responsabilidade de reconstruir se traduziu pela necessidade da conciliação entre as tribos, na perspectiva de recolherem as armas. (DE WAAL, 2007, p. 1.051).

A responsabilidade de reconstruir se dá por meio da repressão dos infratores. Porém, vários autores mostram como a repressão por parte do TPI pode enfraquecer ou pôr em xeque a tentativa de reconciliação interna. (MILLS, 2015, p. 82-83).

Quanto ao Conselho de Segurança, ele pode usar a responsabilidade de proteger em caso de ausência de uma justificativa melhor. (MILLS, 2015, p. 81).

A Resolução n. 1.593 do Conselho de Segurança é a sua primeira referência ao Tribunal Penal Internacional. (WILSON, 2014, p. 166).

Said (1979, p. 14) cita o exemplo de John Stuart Mill que via os Indianos como incapazes de viver num sistema representativo. 


\section{A situação no Darfur}

O conflito no Darfur começou com falhas na governança local. Independente até 1916, ele se tornou uma província esquecida de Sudão e sofreu as influências da guerra civil no Chad a partir da década de 1980. Além das implicações tribais desta guerra civil no país vizinho, os habitantes tiveram que enfrentar as tribos árabes do Norte apoiadas na pilhagem dos povos do sul pelo governo. (DE WAAL, 2007, p. 1.039-1.040).

Nada foi feito a respeito pela comunidade internacional até 2004, ano em que o Departamento de Estado Americano considerou que genocídio podia se estender a crimes cometidos na contrainsurgência. Porém, esse relatório concluiu que essa análise não teria impacto sobre a política americana. Foi tido como competência do CSNU. A União Africana (UA) foi associada a esse processo de paz. Foram assim perdidos mais dois anos em negociações estéreis entre o Sudão, a ONU e a UA. (DE WAAL, 2007, p. 1.042).

A Resolução n. 1.769 do CSNU, de 31 de julho de 2007, criou e fixou o mandato de uma força híbrida ONU - AU. O caráter híbrido foi a causa de muitos problemas, a começar por problemas financeiros, que impediram o pleno desenvolvimento da missão de paz. (DE WAAL, 2007, p. 1.042; p. 1.044-1.045).

O Sudão não é um Estado parte no Estatuto de Roma. No entanto, uma vez que o Conselho de Segurança das Nações Unidas (CSNU) encaminhou a situação em Darfur ao TPI na Resolução n. 1.593 (2005) em 31 de março de 2005, o TPI pode exercer sua jurisdição sobre os crimes enumerados no Estatuto de Roma cometidos no território de Darfur, Sudão, ou por seus nacionais a partir de 1 de julho de 2002. (INTERNATIONAL CRIMINAL COURT, 2005, tradução nossa).

As alegações de genocídio, crimes de guerra e crimes contra a humanidade cometidos em Darfur, no Sudão, desde 1 de julho de 2002 (quando o Estatuto de Roma entrou em vigor). O foco regional atual: Darfur (Sudão), com divulgação para os refugiados no leste do Chade e os exilados em toda a Europa. As investigações sobre Omar al-Bashir focam em alegações de genocídio, crimes de guerra e crimes contra a humanidade cometidos em Darfur, no Sudão, desde 1 de julho de 2002.

O Conselho de Segurança das Nações Unidas (CSNU) determinou que "a situação no Sudão continua a constituir uma ameaça para a paz e a segurança internacionais" e encaminhou esta situação ao TPI em março de 2005, tomando nota do relatório da Comissão internacional de inquérito sobre violações do direito internacional humanitário e direito dos direitos humanos no Darfur (S/2005/60). (INTERNATIONAL CRIMINAL COURT, 2005, tradução nossa). O secretário-geral das Nações Unidas estabeleceu à Comissão 
investigar relatórios de violações do direito internacional humanitário e dos direitos humanos em Darfur por todas as partes, para determinar também se atos de genocídio foram cometidos ou não e identificar os autores de tais violações visando assegurar que os responsáveis sejam responsabilizados. (INTERNATIONAL CRIMINAL COURT, 2005, tradução nossa).

A Comissão tomou como ponto de partida dois fatos:

Primeiro, de acordo com as estimativas das Nações Unidas, existem 1,65 milhão de pessoas internamente deslocadas em Darfur e mais de 200 mil refugiados de Darfur no vizinho Chade. Em segundo lugar, houve destruição em larga escala de aldeias em todos os três estados de Darfur. (INTERNATIONAL CRIMINAL COURT, 2005, tradução nossa).

A investigação iniciada em junho de 2005, encontrou vários casos com suspeitos que vão desde funcionários do governo sudanês, líderes da Milícia / Janjaweed e líderes da Frente da resistência. As acusações incluem os seguintes crimes:

- genocídio: atos de extermínio e assassinato, causar sérios danos corporais ou mentais a grupos protegidos; premeditação de atos a provocar a destruição física dos grupos protegidos; (INTERNATIONAL CRIMINAL COURT, 2005, tradução nossa).

- crimes de guerra: assassinato; ataques contra a população civil; destruição de propriedade; estupro; pilhagem; atos atentatórios a dignidade de indivíduos; violência à vida e à pessoa; ataques intencionais contra pessoal, instalações, material, unidades ou veículos envolvidos em uma missão de manutenção da paz; (INTERNATIONAL CRIMINAL COURT, 2005, tradução nossa). e

- crimes contra a humanidade: como assassinato; perseguição; transferência forçada de população; estupro; atos desumanos; prisão ou privação severa de liberdade; tortura; extermínio. (INTERNATIONAL CRIMINAL COURT, 2005, tradução nossa).

A situação em Darfur foi a primeira a ser encaminhada ao TPI pelo Conselho de Segurança das Nações Unidas e a primeira investigação da corte no território de um Estado não parte no Estatuto de Roma. Foi, também, a primeira investigação sobre alegações do crime de genocídio. O presidente do Sudão, Omar al-Bashir, foi o primeiro acusado pelo crime de genocídio que exercia cargo de chefe de Estado. Os dois mandados de prisão expedidos, entretanto, não foram cumpridos.

Em março de 2009, foi decretada a prisão preventiva em desfavor de Omar al-Bashir, nacionalidade sudanesa, nascido em $1^{\circ}$ de janeiro de 1944 , na província Hoshe Bannaga, Shendi, membro da tribo Jaali e atual presidente da República do Sudão, o qual foi condenado por sete crimes de interesse internacional, dois crimes de guerra (ataque a civis e pilhagem) e cinco crimes contra humanidade (homicídio, extermínio, deslocamento 
forçado, tortura e estupro), perpetrados sob sua liderança desde o ano de 2003 na região de Darfur. (INTERNATIONAL CRIMINAL COURT, 2005, tradução nossa).

A decisão foi fundamentada sob a égide do Estatuto de Roma nos termos do art. 19, item 1, art. 58, item 1, alínea “ $b$ ” (i, ii, iii) e art. 25 , item 3 , alínea “ $a$ ". (ALMEIDA; VILALONGA; PATRÍCIO, 2002, p. 26, 30 e 56).

A Câmara de julgamento, após a verificação de todo o conjunto probatório, ficou convencida de que havia motivos suficientes para acusar Omar Hassan Ahmad alBashir, como o responsável pelas atrocidades ocorridas na região de Darfur e decretou a prisão de Omar. A decisão aponta indícios suficientes de autoria e materialidade, diante da existência dos seguintes fatos: ${ }^{2}$

a) ocorrência de um conflito armado sem caráter internacional e previsto no art. $8^{\circ}$, item 2, alínea " $f$ " do estatuto, no período de março de 2003 até pelo menos 14 de julho de 2008, entre o governo do Sudão conhecido como " $G S$ ” e outros grupos armados (crime organizado), em particular o Movimento / Exército Libertador do Sudão (M/ELS) e o Movimento pela Justiça e Igualdade (MJ) ${ }^{3}$

b) lançamento de um apelo geral pelo GS para a mobilização da milícia Janjaweed, em resposta às atividades do Movimento / Exército libertador do Sudão (M/ ELS), Movimento pela justiça e igualdade (MJI) e outros grupos de oposição armada, em Darfur. Logo após o ataque no aeroporto de El Fasher, em abril de 2003 houve uma campanha de contrainsurgência, também conhecida como plano comum, em toda a região de Darfur em desfavor dos grupos armados de oposição. Essa campanha foi conduzida pela Polícia sudanesa, Agência Nacional de Inteligência, serviço de segurança e pela Comissão de ajuda humanitária, sob a liderança do " $G S$ ”, em conjunto com as Forças armadas sudanesas e seus aliados da milícia Janjaweed. A campanha de contrainsurgência continuou até a data do depósito do pedido de investigação do Ministério público, em 14 de julho de 2008, evidenciando a ocorrência de crimes de guerra, ataque a civis e

$2 \quad$ “(..) in which the Chamber held that it was satisfied that there are reasonable grounds to believe that Omar Al Bashir is criminally responsible under article 25(3)(a) of the Statute as an indirect perpetrator, or as an indirect co-perpetrator, for war crimes and crimes against humanity and that his arrest appears to be necessary under article 58(l)(b) of the Rome Statute ("the Statute")". (INTERNATIONAL CRIMINAL COURT, 2005, tradução nossa).

3 "That there are reasonable grounds to believe that from March 2003 to at least 14 July 2008, a protracted armed conflict not of an international character within the meaning of article 8(2)(f) of the Statute existed in Darfur between the Government of Sudan ("the GoS") and several organised armed groups, in particular the Sudanese Liberation Movement/Army ("the SLM/A") and the Justice and Equality Movement ("the JEM")”. (INTERNATIONAL CRIMINAL COURT, 2005, tradução nossa). 
pilhagem, todos previstos nos arts. $8^{\circ}, \S 2^{\circ}$, alínea “ $e$ ” (i $)^{4}$ e art. $8^{\circ}, \S 2^{\circ}$, alínea " $e$ ” $(v)^{5}$ do estatuto, ${ }^{6}$

c) formação de um núcleo advindo da campanha contrainsurgência de grupos rebeldes no Sudão, que atacaram ilegalmente parte da população civil de Darfur como os povos Fur, Masalit e Zaghawa, que foram considerados pelo GS povos aliados ao M/ELS, MEJI e outros grupos armados de oposição. Por esse motivo, as forças do Sudão tomaram e saquearam as cidades e as aldeias desses povos por meio de ataques armados; ${ }^{7}$

d) Esses ataques ilegais do GS foram generalizados e afetaram milhares de pessoas, levando o terror a grande parte do território da região de Darfur. Milhares de civis foram submetidos a atos de homicídio e extermínio (art. $7^{\circ}, \S 1^{\circ}$, alíneas " $a$ " e “ $b$ ”). As forças do Sudão submeteram a população civil a atos de transferência forçada e tortura, principalmente os grupos Masalit e Zaghawa, sendo que a maioria das mulheres pertencentes a estes grupos foram submetidas a atos de estupro, caracterizando os crimes contra a humanidade previstos no art. $7^{\circ}, \S 1^{\mathrm{o}}$, alíneas " $d$ ", " $f$ " e " $g$ " do Estatuto de Roma. $^{8}$

$4 \quad$ Art. $8^{\circ}, \S 2^{\circ}$, alínea "e" (i) - "Atacar intencionalmente a população civil em geral ou civis que não participem diretamente nas hostilidades".

5 Art. $8^{\circ}, \S 2^{\circ}$, alínea "e" (v) - "Saquear um aglomerado populacional ou um local, mesmo quando tomado de assalto".

$6 \quad$ "that there are reasonable grounds to believe: (i) that soon after the attack on El Fasher airport in April 2003, the GoS issued a general call for the mobilisation of the Janjaweed Militia in response to the activities of the SLM/A, the JEM and other armed opposition groups in Darfur, and thereafter conducted, through GoS forces, including the Sudanese Armed Forces and their allied Janjaweed Militia, the Sudanese Police Force, the National Intelligence and Security Service ("the NISS") and the Humanitarian Aid Commission ("the HAC"), a counterinsurgency campaign throughout the Darfur region against the said armed opposition groups; and (ii) that the counter-insurgency campaign continued until the date of the filing of the Prosecution Application on 14 July 2008; that there are reasonable grounds to believe: (i) that a core component of the GoS counter-insurgency campaign was the unlawful attack on that part of the civilian population of Darfur - belonging largely to the Fur, Masalit and Zaghawa groups - perceived by the GoS as being close to the SLM/A, the JEM and the other armed groups opposing the GoS in the ongoing armed conflict in Darfur; and (ii) that, as part of this core component of the counter-insurgency campaign, GoS forces systematically committed acts of pillaging after the seizure of the towns and villages that were subject to their attacks; evidences war crimes within the meaning of articles 8(2)(e)(i) and 8(2)(e)(v) of the Statute were committed". (INTERNATIONAL CRIMINAL COURT, 2005, tradução nossa).

7 "that there are reasonable grounds to believe that, as part of the GoS's unlawful attack on the abovementioned part of the civilian population of Darfur and with knowledge of such attack, GoSforces subjected, throughout the Darfur region, thousands of civilians, belonging primarily to the Fur, Masalit and Zaghawa groups". (INTERNATIONAL CRIMINAL COURT, 2005, tradução nossa).

8 "that there are also reasonable grounds to believe that, as part of the GoS's unlawful attack on the abovementioned part of the civilian population of Darfur and with knowledge of such attack, GoS forces subjected, throughout the Darfur region, to acts of murder and extermination, hundreds of thousands of civilians, belonging primarily to the Fur, Masalit and Zaghawa groups, to acts of forcible transfer; thousands of civilian women, belonging primarily to these groups, to acts of rape; and civilians, belonging primarily to the same groups, to acts of torture; therefore that there are reasonable grounds to believe that, from soon after the April 2003 attack on El Fasher airport until 14 July 2008, GoS forces, including the Sudanese armed Forces and their allied Janjaweed Militia, the Sudanese police Force, the NISS and the 
Restou provado que Omar Hassan Ahmad al-Bashir tem sido, de fato, presidente do Estado do Sudão e comandante-chefe das forças armadas desde março de 2003 até 14 de julho de 2008 e que, nessa posição, assumiu um papel fundamental na coordenação, junto a outros altos líderes políticos e militares, na concepção e implementação da referida campanha contrainsurgência de grupos armados. ${ }^{9}$

Omar al-Bashir utilizou do controle de todos os ramos do "aparelho" do Estado do Sudão, tais como: Forças armadas, milícias Janjaweed, polícia, Agência nacional de inteligência, Serviço de segurança e da Comissão de ajuda humanitária, para garantir a implementação da campanha contrainsurgência e assegurar sua impunidade. ${ }^{10}$

Por tais razões, o presidente Omar al-Bashir, foi considerado criminalmente responsável como autor indireto e coautor indireto, por força do art. $25, \S 3^{\circ}$, alínea " $a$ " do Estatuto de Roma, pelas práticas delitivas previstas nos artigos: art. $7^{\circ}, \S 1^{\circ}$, alíneas “ $a$ ”, “b”, “d”, “ $f ”$ e “g” e art. $8^{\circ}, \S 2^{\circ}$, alínea “e” (i) e art. $8^{\circ}, \S 2^{\circ}$, alínea “e” (v)..$^{11}$

A execução do mandado de prisão do presidente do Sudão carece de mecanismos para mandá-lo à Corte Internacional. ${ }^{12}$

Os militares que se encontram em missão no solo sudanês, em virtude de outros propósitos, não podem executar as decisões do TPI, pois não possuem mandato para

$H A C$, committed crimes against humanity consisting of murder, extermination, forcible transfer, torture and rape, within the meaning of articles $7(1)(a),(b),(d),(f)$ and $(g)$ respectively of the Statute, throughout the Darfur region". (INTERNATIONAL CRIMINAL COURT, 2005, tradução nossa).

9 "that there are reasonable grounds to believe that Omar Al Bashir has been the de jure and de facto President of the State of Sudan and Commander-in-Chief of the Sudanese Armed Forces from March 2003 to 14 July 2008, and that, in that position, he played an essential role in coordinating, with other highranking Sudanese political and military leaders, the design and implementation of the above-mentioned GoS counter-insurgency campaign”. (INTERNATIONAL CRIMINAL COURT, 2005, tradução nossa).

10 "further, that the Chamber finds, in the alternative, that there are reasonable grounds to believe: (i) that the role of Omar Al Bashir went beyond coordinating the design and implementation of the common plan; (ii) that he was in full control of all branches of the "apparatus" of the State of Sudan, including the Sudanese Armed Forces and their allied Janjaweed Militia, the Sudanese Police Force, the NISS and the HAC; and (iii) that he used such control to secure the implementation of the common plan". (INTERNATIONAL CRIMINAL COURT, 2005, tradução nossa).

11 "for the above reasons, there are reasonable grounds to believe that Omar Al Bashir is criminally responsible as an indirect perpetrator, or as an indirect co-perpetrator, under article 25(3)(a) of the Statute, for: $i$. intentionally directing attacks against a civilian population as such or against individual civilians not taking direct part in hostilities as a war crime, within the meaning of article 8(2)(e)(i) of the Statute; ii. pillage as a war crime, within the meaning of article 8(2)(e)(v) of the Statute; iii. murder as a crime against humanity, within the meaning of article $7(l)(a)$ of the Statute; iv. extermination as a crime against humanity, within the meaning of article $7(l)(b)$ of the Statute; $v$. forcible transfer as a crime against humanity, within the meaning of article $7(1)(d)$ of the Statute; vi. torture as a crime against humanity, within the meaning of article $7(l)(f)$ of the Statute; and vii. rape as a crime against humanity, within the meaning of article $7(1)(g)$ of the Statute”. (INTERNATIONAL CRIMINAL COURT, 2005, tradução nossa).

12 Acerca dos mandados de prisão emitidos pelo TPI, a procuradora da Corte internacional, Louise Arbour, relatou que para a eficácia das ordens de detenção, a solução seria não divulgar alguns atos da acusação, deixando assim os acusados à mercê de uma prisão em outro país na ocasião de um deslocamento. (BAZELAIRE; CRETIN, 2004, p. 99). 
cumprir suposta tarefa, e porque só respondem diretamente ao Conselho de Segurança da ONU, e não ao TPI, o qual independe das Nações Unidas. (IDE, 2009).

Segundo Diogo Mamoru, rebatendo interpretações de que a expedição do primeiro mandado internacional de prisão do Tribunal Penal Internacional, em desfavor a um chefe de estado em exercício apresentava indícios do fortalecimento do Direito Internacional Penal e também uma prova crescente de aceitação de que indivíduos devem ser responsabilizados no plano internacional por atos ilícitos, cuja posição, contudo ao ver do citado autor, não deve prosperar, pois instâncias internacionais de persecução penal possuem jurisdição sobre casos restritos e altamente seletivos e que grande parte da implementação do Direito Penal se encontra nas mãos dos próprios Estados. (IDE, 2009).

$\mathrm{O}$ apoio prestado por China, União Africana e Liga Árabe ao presidente Omar al-Bashir, refletiu que existem prioridades maiores que os princípios e valores de proteção da pessoa humana, tais como a política e economia, que forçam a moral internacional a trilhar por outros rumos e ir em busca de mecanismos que possam satisfazer a prática. (IDE, 2009).

O presidente Omar al-Bashir, desde a data do lançamento do mandado de prisão, não se encontra preso até os dias atuais, pois rejeitou a decisão do TPI com o apoio declarado. Com isso, é possível aferir que a responsabilização de indivíduos em âmbito internacional pode estar condicionada e influenciada pela dinâmica da política interestatal.

Vale a pena retomar os eventos na ordem cronológica para avaliar melhor o andamento do Conselho de Segurança acerca do Darfur.

\begin{tabular}{|l|l|l|}
\hline \multicolumn{1}{|c|}{ Data } & \multicolumn{1}{|c|}{ Eventos } & \multicolumn{1}{|c|}{ Decisões } \\
\hline Abril de 2006 & \multicolumn{1}{|c|}{$\begin{array}{l}\text { Resolução n. 1.672 identificando } \\
\text { alvos para as sanções da } \\
\text { Resolução n. 1.591. }\end{array}$} \\
\hline Julho de 2007 & $\begin{array}{l}\text { Resolução n. 1.769 criando a } \\
\text { UNAMID. }\end{array}$ \\
\hline Julho de 2008 & $\begin{array}{l}\text { Moreno Ocampo do pedido de prisão } \\
\text { contra al-Bashir. Intensa ofensiva } \\
\text { diplomática do Sudão em particular } \\
\text { na Liga árabe e na União africana para } \\
\text { conter esse pedido, suspendendo os } \\
\text { procedimentos perante o TPI com base } \\
\text { no art. 16 do Estatuto de Roma. }\end{array}$ & $\begin{array}{l}\text { Primeiro mandato de prisão } \\
\text { contra al-Bashir. }\end{array}$ \\
\hline Março de 2009 & \multicolumn{1}{|c|}{$\begin{array}{l}\text { Anião Africana decide em } \\
\text { Sirte de não cooperar com o } \\
\text { mandato de prisão contra al- } \\
\text { Bashir. }\end{array}$} \\
\hline
\end{tabular}




\begin{tabular}{|c|c|c|}
\hline Novembro de 2009 & Fim das negociações em Doha & \\
\hline Julho de 2010 & $\begin{array}{l}\text { Primeira reunião do Sudan consultative } \\
\text { Forum, organismo visando a coordenar } \\
\text { o apoio internacional para transformação } \\
\text { democrática do país. }\end{array}$ & $\begin{array}{l}\text { Segundo mandato de prisão } \\
\text { contra al-Bashir por genocídio } \\
\text { contra os grupos Fur, Masalit e } \\
\text { Zaghawa. } \\
\end{array}$ \\
\hline Agosto de 2010 & & $\begin{array}{l}\text { Decisões do TPI informando } \\
\text { o Conselho de Segurança e a } \\
\text { Assembleia dos estados- partes } \\
\text { sobre a visita de al-Bashir ao } \\
\text { Chade e ao Quênia. }\end{array}$ \\
\hline Maio de 2012 & $\begin{array}{l}\text { Acusação sudanesa de que Sudão do sul } \\
\text { ocuparia território do Darfur. }\end{array}$ & \\
\hline Junho de 2012 & $\begin{array}{l}\text { Último relatório do promotor do } \\
\text { TPI Luis Moreno Ocampo pedindo } \\
\text { intervenções dos estados membros no } \\
\text { intuito de dar voz de prisão a al-Bashir. }\end{array}$ & \\
\hline Setembro de 2013 & $\begin{array}{l}\text { Pedido do TPI aos Estados Unidos de } \\
\text { apreenderem al-Bashir em caso de visita } \\
\text { oficial. }\end{array}$ & \\
\hline Junho de 2017 & $\begin{array}{l}\text { Último ataque contra a força de } \\
\text { manutenção da paz. }\end{array}$ & \\
\hline Julho de 2018 & & $\begin{array}{l}\text { Adoção por unanimidade da } \\
\text { Resolução n. } 2.429 \text { estendendo } \\
\text { o mandato da UNAMID. }\end{array}$ \\
\hline Outubro de 2018 & $\begin{array}{l}\text { A embaixadora Joanna Wronecka da } \\
\text { Polônia encaminhou o relatório do } \\
\text { Comitê de sanções. }\end{array}$ & \\
\hline Dezembro de 2018 & $\begin{array}{l}\text { Fatou Bensouda, promotor do TPI, } \\
\text { encaminhou o relatório semi-anual } \\
\text { sobre Darfur. As violências diminuiram, } \\
\text { mas a impunidade persiste. }\end{array}$ & \\
\hline Fevereiro de 2019 & & $\begin{array}{l}\text { Resolução n. } 2.455 \text { expressando } \\
\text { "a intenção do Conselho de } \\
\text { Segurança de estabelecer } \\
\text { referências claras, bem identifi- } \\
\text { cadas e mensuráveis que podem } \\
\text { ajudar o Conselho a se guiar } \\
\text { para revisar medidas contra o } \\
\text { governo do Sudão". }\end{array}$ \\
\hline Abril de 2019 & $\begin{array}{l}\text { Relatório do vice-secretário geral ao } \\
\text { Conselho de Segurança sobre o golpe } \\
\text { militar que depôs o ex-presidente Omar } \\
\text { al-Bashir. }\end{array}$ & \\
\hline
\end{tabular}


Como podemos ver, a ONU funciona essencialmente com base em relatórios das agências da família da ONU e das ONGs, mas, sobretudo do TPI que a cada seis meses oferecem a evolução dos casos em andamento.

Outro ponto interessante a destacar é o relatório do responsável pelo comitê de sanções.

De tudo o que precede, podemos perceber a evolução e a resiliência das tensões étnicas no país. A atual situação política é um motivo de preocupação para a comunidade internacional que não tem certeza se o ex-presidente Omar al-Bashir será entregue ou não. Os motivos reais do golpe militar do mês de abril de 2019 no Sudão ainda permanecem nebulosos.

Quanto à intervenção ocidental, ela se mostrou demorada e às vezes hesitante demais.

Mas podemos dizer que sem ela o Darfur teria conhecido uma situação ainda pior.

São Paulo, abril de 2019.

\section{Referências}

ALMEIDA, Carlota Pizarro de; VILALONGA, José Emanuel; PATRÍCIO, Rui. Estatuto de Roma do Tribunal Penal Internacional: e textos complementares. Lisboa: Almedina, 2002.

BAZELAIRE, Jean-Paul; CRETIN, Thierry. A justiça penal internacional: sua evolução, seu futuro de Nuremberg a Haia. São Paulo: Manole, 2004.

DE WAAL, Alexander. Darfur and the failure of the responsibility to protect. International Affairs, London, v. 83, n. 6, p. 1.039-1.054, 2007.

GIANNATTASIO, Arthur Roberto Capella. The interaction between international and domestic legal orders: framing the debate according to the post-modern condition of international law. German Law Review, Lexington, v. 19, n. 1, p. 1-20, Feb. 2018.

IANCU, Andreea. The responsibility to protect. A just war theory based analysis. SEA-Practical Application of Science, Iaşi, v. 2, n. 5, p. 341-348, 2014.

IDE, D. O mandado de prisão do TPI contra al-Bashir à luz da relação entre poder e moral internacionais. Meridiano 47 - Journal of Global Studies, Brasília, v. 10, n. 105, p. 30-33, abr. 2009. Disponível em: http://periodicos.unb.br/index.php/MED/article/view/3616/3297. Acesso em: 29 mar. 2019. 
INTERNATIONAL COMMISSION ON INTERVENTION AND STATE SOVEREIGNTY. The responsibility to protect: report of the International Commission on Intervention and State Sovereignty. Ottawa: International Development Research Centre, 2001. Disponível em: http:// responsibilitytoprotect.org/ICISS\%20Report.pdf.

INTERNATIONAL CRIMINAL COURT. Trying individuals for genocide, war crimes, crimes against humanity, and aggression. Situation in Darfur, Sudan. ICC-02/05. 2005. Disponível em: https://www.icc-cpi.int/darfur. Acesso em: 2 fev. 2019.

MILLS, Kurt. R 2 P and the ICC: at odds or in sync? Criminal Law Forum, Dordrecht, v. 26, n. 1, p. 73-99, March 2015.

ROY, Denis. Nabil Hajjami. La responsabilité de protéger, Bruxelles, Bruylant, 2013. Revue Québécoise de Droit International, Montreal, v. 27, n. 2, p. 209-212, 2014.

SAID, Edward Wadie. Orientalism. New York: Vintage Books, 1979.

SASSÒLI, Marco. Mise en œuvre du droit international humanitaire et du droit international des droits de l'homme: une comparaison. Annuaire Suisse de Droit International, Zürich, v. 43, p. 24$61,1987$.

THAKUR, Ramesh. Review article. The responsibility to protect at 15. International Affairs, London, v. 92, n. 2, p. 415-434, 2016.

UNITED NATIONS. Security Council. Security Council creates United Nations support mission in Libya, adopting Resolution 2009 (2011). 6620 ${ }^{\text {th }}$ Meeting (PM). SC/10389. Sept. 2011. Disponível em: https:/www.un.org/press/en/2011/sc10389.doc.htm. Acesso em: 7 nov. 2018.

WILSON, Gary. Applying the responsibility to protect to the 'Arab Spring'. Liverpool Law Review, Dordrecht, v. 35, n. 2, p. 157-173, 2014.

WOODWARD, Scoot. The responsibility to protect: the time is now. Mediterranean Quarterly, Washington, DC, v. 23, n. 3, p. 82-97, Summer 2012. 